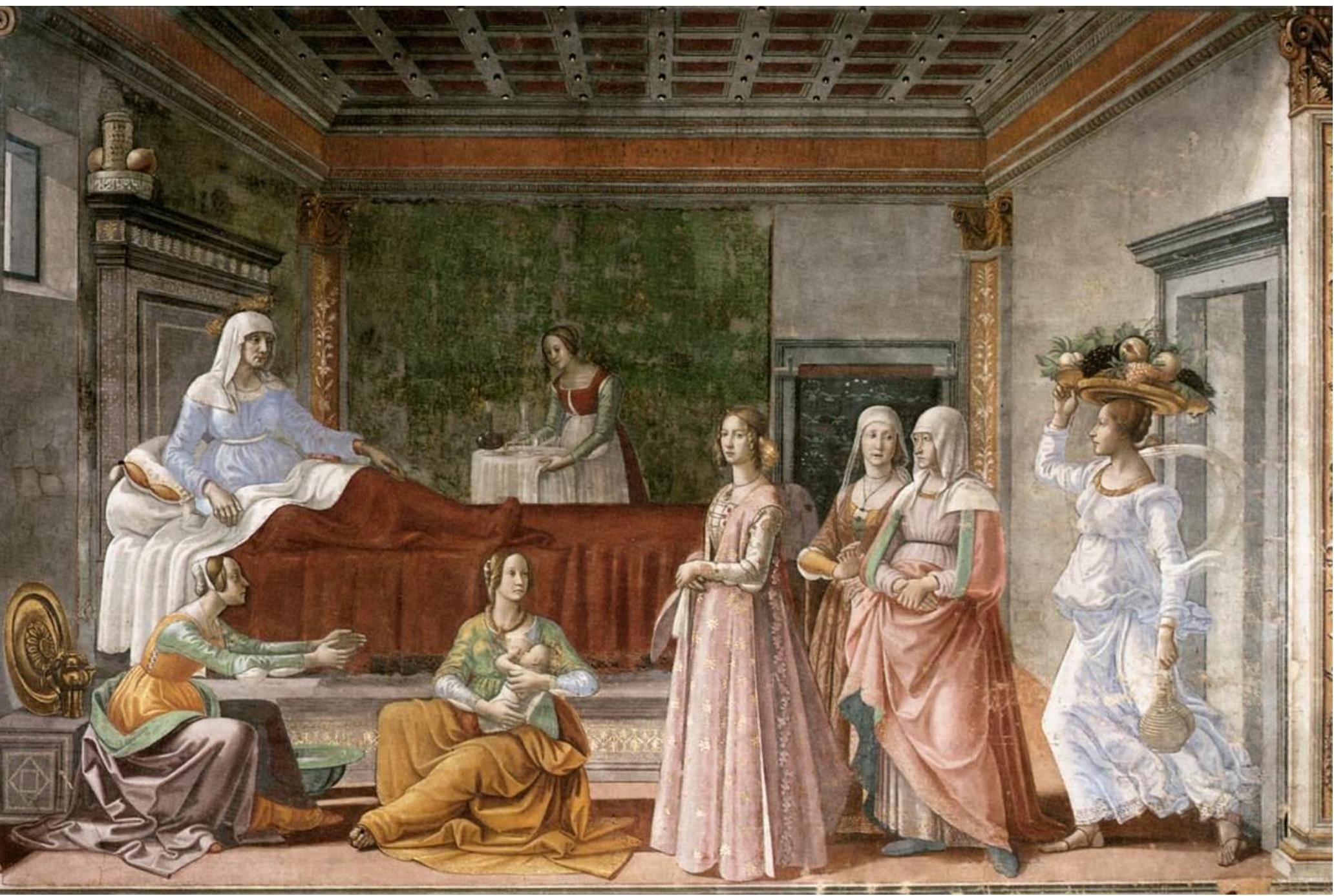

\title{
A Ninfa como personagem teórica de Aby Warburg
}

The Nymph as a theoretical character of Aby Warburg

\author{
Dra. Daniela Queiroz Campos
}

Como citar:

CAMPOS, D.Q. A Ninfa como personagem teórica de Aby Warburg. MODOS. Revista de História da Arte. Campinas, v. 4, n.3, p.225-245, set. 2020. Disponivel em: <https://www.publionline.iar.unicamp.br/ index.php/mod/article/view/4567>.

DOI: <https://doi.org/10.24978/mod.v4i3.4567>.

Imagem: Domenico Ghirlandaio. O Nascimento de São João Batista, afresco, 1485-1490. Santa Maria Novella, Florença. Fonte: (DidiHuberman, 2002). 


\title{
A Ninfa como personagem teórica de Aby Warburg
}

\author{
The Nymph as a theoretical character of Aby Warburg
}

\section{Dra. Daniela Queiroz Campos*}

\begin{abstract}
Resumo
O presente artigo objetiva abordar a ninfa como personagem nas obras do historiador da arte Aby Warburg. Para alcançar tal intento, se exercitará uma dupla atividade de investigação. A ninfa será pesquisada a partir das apresentações imagéticas analisas pelo historiador da arte alemão, mas também como personagem teórica, na qual pode-se perceber parte considerável dos preceitos imagéticos cunhados por Warburg, tais quais: Nachleben - cunhado por Springer -, Pathosformel e Mnemosyne. Este artigo foi dividido em três principais partes, cada uma delas tem como mote um texto e um conceito. Partiu-se da correspondência da "Ninfa Florentina" e do conceito de Nachleben. Em seguida, analisou-se a tese de doutorado sobre "O Nascimento de Vênus e a Primavera de Sandro Botticelli" e a Pathosformel. E num terceiro momento, o conceito de memória foi problematizado no Bilderatlas Mnemosyne. Para além dos escritos de Aby Warburg, este artigo aponta uma pós-vida da personagem também por meio de exegetas do historiador da arte que pesquisam e escrevem sobre a temática nos séculos XX e XXI.
\end{abstract}

\section{Palavras-chave}

Aby Warburg. Ninfa. Nachleben. Pathosformel. Bilderatlas Mnemosyne.

\begin{abstract}
This article addresses the nymph as a character in the works of the art historian Aby Warburg. To achieve this goal, I proceeded with two research approaches. The Nymph was studied from the analytical presentations by the German art historian but also as a theoretical character, in whom we can perceive part of the precepts imagined by Warburg, such are: Nachleben - created by Springer -, Pathosformel, and Mnemosyne. This article has been divided in three main parts, each constructed around a text and a concept. The first part starts discussing the correspondence between the "Ninfa Florentina" and the concept of Nachleben. Afterward, we review the PhD thesis on "The Birth of Venus and the spring by Sandro Botticelli" and the Pathosformel. And in the third moment, the concept of memory is problematized in the Bilderatlas Mnemosyne. In addition to Aby Warburg's writings, this article also indicates the character's afterlife through the history of the art and the researches and writings on the subject in the XX and XXI centuries.
\end{abstract}

\section{Keywords}

Aby Warburg. Nymph. Nachleben. Pathosformel. Bilderatlas Mnemosyne. 
Aby Warburg redigiu páginas e mais páginas sobre a incrível e complexa disciplina que tem a arte como seu objeto de estudo. Ele também selecionou uma infinidade de imagens e as apresentou em múltiplas pranchas negras que resultaram em seu último e inacabado trabalho: Bilderatlas Mnemosyne. Para além de uma porção de textos e montagens de imagens, Warburg deixou-nos uma incrivel biblioteca labiríntica (Settis, 2010: 54) que veio a ser tornar um instituto de pesquisa. Todavia, talvez, a grande contribuição desse historiador da arte hamburguês tenha sido fluida e translúcida como o vento. Georges Didi-Huberman escreveu que Aby Warburg colocara a história da arte em movimento. Depois dele, a disciplina já não estaria mais diante da imagem e diante do tempo como antes (Didi-Huberman, 2013: 25).

O tempo homogêneo e consecutivo da história da arte foi rompido a partir de proposições de análises de imagens que foram produzidas em diferentes épocas e contextos. 0 objeto outrora cercado pela disciplina parece ter se contaminado e se ampliado pelos movimentos das águas do mar, do vento ou do mármore. $\mathrm{E}$ fora justamente o movimento que intrigara $\mathrm{o}$ ainda bastante jovem historiador da arte em sua tese doutoral. O movimento aparente que os artistas do Quattrocento encontraram nos mármores que sobreviveram à Antiguidade. Esses mármores, muitas vezes, apresentavam as vestes agitadas de figuras femininas, de deusas e semideusas daquele antigo paganismo. Figuras femininas estas que foram identificas, ou melhor, nomeadas como ninfas.

Aby Warburg escreveu diretamente sobre as ninfas em três de seus textos. Na tese de doutorado 0 Nascimento de Vênus e a Primavera de Sandro Botticelli de 1892 (Warburg, 2015), na correspondência fictícia trocada com André Jolles entre 1900 e 1901 (Warburg, 2018) e no texto "O ingresso do estilo ideal antiquizante na pintura do Primeiro Renascimento" de 1914 (Warburg, 2018). Às ninfas 0 historiador dedica, ademais, as Pranchas 39, 46, 77 de seu Bilderatlas Mnemosyne (1927-1929) (Warburg, 2010). Em boa verdade, podemos perceber imagens e fragmentos de textos sobre as ninfas em outras tantas pranchas de seu Atlas imagético e em muitas páginas dispersas de seus textos.

Temporalmente, numa visão ligeira, os escritos sobre as ninfas parecem estar restritos entre o final do século XIX até a terceira década do século XX. Entretanto, para olhos perspicazes, tais divindades menores saltaram a linha organizada do tempo do historiador e parecem ter bem pousado no limiar de outros dois séculos - entre o final do XX e início do XXI. E a ninfa é então (re)vista e sobre ela se (re)escreve. Sua atividade de retorno se dá como um verdadeiro Nachleben de Warburg. Como imagem, ela não retorna exatamente da mesma maneira que fora outrora. Trata-se de outra apresentação, de uma nova encarnação, de uma outra vida.

A personagem de Warburg passa a ser também a personagem de outros tantos historiadores da arte, historiadores da arte warburguianos. Podemos situá-la num momento histórico e num processo de revisitação dos textos do historiador da arte hamburguês que tem acontecido com singular potência no século XXI. Segundo Fernando Checa, no começo da segunda década desde século Warburg aparece como o mais importante historiador da arte do século anterior e não como o mais influente (Checa, 2010: 11).

\section{A ninfa que corre}

Neste artigo não vou começar pelo início. Explico-me: meu problema aqui não parte do primeiro texto que Aby Warburg redigiu sobre as ninfas. Iniciarei, assim, pela fração que julgo mais poética, a que 0 historiador da arte escreveu de maneira quase apaixonada por aquela que veio a se transformar em sua grande personagem. A que é considerada a grande ninfa warburguiana. A que habita o coro da 
Igreja florentina de Santa Maria Novella e que ganhou feições e cores pelas pinceladas de Domenico Ghirlandaio (1448-1494) sobre o afresco.

A figura feminina em questão foi pintada na cena de O Nascimento de São João Batista (1490), que por sua vez pertence a uma série de afrescos que Domenico Ghirlandaio pintou por encomenda de Giovanni Tornabuoni na capela da qual o último era patrono (Warburg, 2013: 176). Como Aby Warburg bem nos lembra, o coro de Santa Maria Novella era o lugar de sepultamento, "(...) o lugar de sepultura mais solene que os combativos monges dominicanos podiam consignar" (Warburg, 2018: 72).

Como expressão da incrivel polaridade diante das quais as imagens warburguianas insistem em nos colocar, a imagem em questão narra um nascimento. O nascimento do santo que se tornou iconograficamente mais conhecido por sua morte. A história da arte - tanto como disciplina, como sua fração que remete à somatória de "(...) obras e imagens que se sucedem na história da humanidade" (Huchet, 2014: 224) - habilitou nossos olhos a ver São João Batista morto e com a cabeça decapitada sobre uma bandeja de prata. Mas, na imagem analisada, vemos seu nascimento.

0 afresco de Ghirlandaio não apresenta um nascimento propriamente dito, mas um momento que 0 precede. No afresco, vemos o interior luxuoso de um cômodo palacial florentino do século XV e sobre a adornada cama uma parturiente: Santa Isabel, a prima da Vigem Maria. "Aqui, imponentes damas da família Tornabuoni, em dignificante postura de quem se sente parte de uma sociedade de eleitos, congratulam-se com Isabel" (Warburg, 2018: 116).

A cena é composta por nove personagens. Sendo elas: São João Batista - ainda bebê - Santa Isabel, três empregadas, três damas da sociedade florentina do Quattrocento e uma quarta criada. Sete, daquelas oito mulheres a comporem a cena, vestem-se segundo a moda florentina da época, apesar de 0 fato narrado pela imagem ter acontecido na Antiguidade, antes da era Cristã. Pois, segundo a narrativa bíblica, o nascimento de São João Batista antecede ao de seu primo, Jesus Cristo.

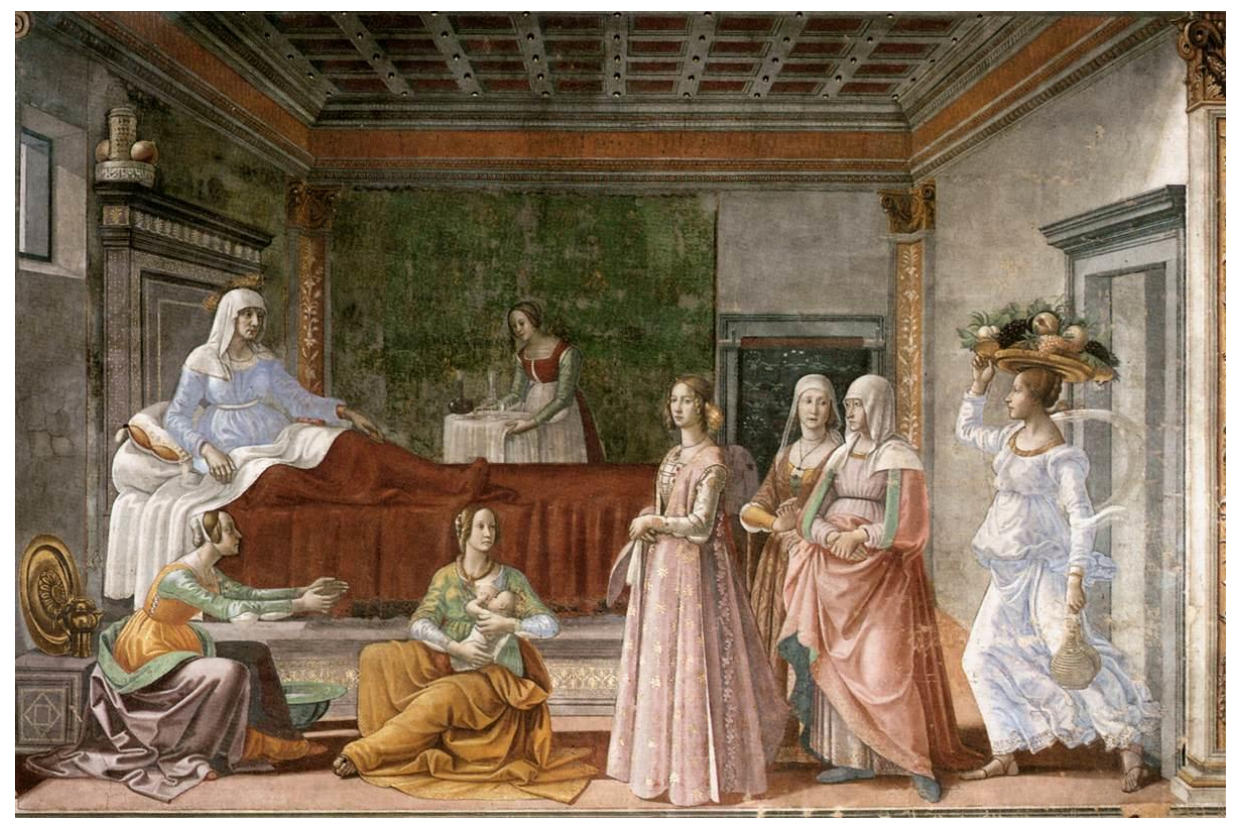

Fig. 1. Domenico Ghirlandaio. O Nascimento de São João Batista, afresco, 1485-1490. Santa Maria Novella, Florença. Fonte: (Didi-Huberman, 2002). 
Nesta cena, especificamente, podemos observar algo que, de certa feita, repete-se em outras imagens do Renascimento florentino analisadas por Aby Warburg. As ninfas, que são divindades pagãs, apresentadas em temas do cristianismo. No Nascimento de São João Batista, a jovem que leva uma cesta de frutas na cabeça e se veste à antiga parece interromper a cena com sua agitação. Essa figura expressiva, a "(...) forma feminina, que Warburg chamou brincando de "senhorita apressada", mas também de deusa pagã no exílio", implicava para ele num claro sintoma de influência da Antiguidade que aparecia em textos e em pintura nomeada como ninfas" (Szir, 2019: 24).

Temos, diante de nossos olhos, uma evidente imbricação temporal, uma cena histórica da Antiguidade apresentada com uma roupagem florentina do século XV. Ao apresentar a cena bíblica, muitos artistas renascentistas pintavam as feições dos rostos de figuras florentinas que lhes eram contemporâneas. Por isso, muito bem insiste Daniel Arasse (2016: 139) que na história da arte não existe sentido na ideia de pureza de um tempo linear. "O anacronismo é o do historiador, mas também o da obra, que mistura os tempos e as durações da História" (Ibidem: 141). A impurezas temporais na história da arte foram umas das grandes potências das investigações de Warburg. Como bem escreveu Fritz Saxl, "a problemática que permeia a Biblioteca Warburg é a pergunta sobre o alcance e a essência da influência da Antiguidade nas culturas posteriores" (Saxl, 2010: 91).

José Emílio Burucúa também sublinha a confirmação da ideia de Warburg, "de que a Ninfa teria sido um leitmotiv perene da evocação vivaz do paganismo ao longo do Renascimento e além dele" (Burucua, 2007: 16). A ninfa seria a figura pagã que, no Renascimento, ganhou apresentação imagética, também encarnada em outras possíveis personagens. Justamente por isso, ela pode ser pensada como uma personagem teórica, pois em muito ela se assemelha às imagens de forma mais ampla. Aquelas que, de um lado são "(...) o patrimônio herdado do passado, e de outro, as impressões do mundo vivo que o circunda" (Warburg, 2018: 199).

Por entre amas-de-leite, criadas e senhoras florentinas uma figura parece escapar e ao mesmo tempo integrar a cena. Ela está ali, mas ao fitá-la temos certeza de que ela não pertence nem àquele tempo, nem àquele lugar. Ela é o descompasso, o contratempo da cena; "(...) caminha apressada uma serva com um frasco na mão e uma bandeja de fruta na cabeça. Não obstante seja destinada a uma tarefa prosaica, a figura é idealmente estilizada: o vestido é apertado e esvoaçante, como o da Vitória" (Ibidem: 116).

O descompasso ritmado da donzela de pés ligeiros em muito se dá pelo branco e drapeado de suas vestes. Ela é a única das oito mulheres em cena que não porta vestido à moda florentina. 0 descompasso do tempo também pode ser notado em seus pés, que têm parte considerável à mostra devido às sandálias características de figuras greco-romanas. Ela se veste como aquelas mulheres da Antiguidade que chegaram ao Renascimento toscano através dos relevos e das esculturas em mármore.

Naquela imagem, Warburg "reparou em representações de figuras femininas como vestes esvoaçantes e voláteis, cabelos soltos e movimentados pelo vento, gestos dinâmicos e quase dançantes, associados a outros elementos (...) que mostram agitação e movimentos" (Szir, 2019: 23).

O conhecido texto sobre a ninfa de Ghirlandaio trata-se de uma correspondência fictícia trocada entre Aby Warburg e André Jolles - também historiador da arte e da literatura holandês. Tais textos compõem um manuscrito que começou a ser escrito - por ambos - na cidade de Florença e jamais foi concluído 
(Didi-Huberman, 2013: 296). A primeira parte desse conjunto de cartas foi escrita no ano de 1900 por Jolles e a segunda foi redigida por Warburg, em 1901. Tais textos receberam a primeira tradução para o português pela Editora de Lisboa KKYM, no ano de 2015. E mais recentemente, no ano 2018, foram também traduzidas e editadas no Brasil pela Editora da Unicamp.

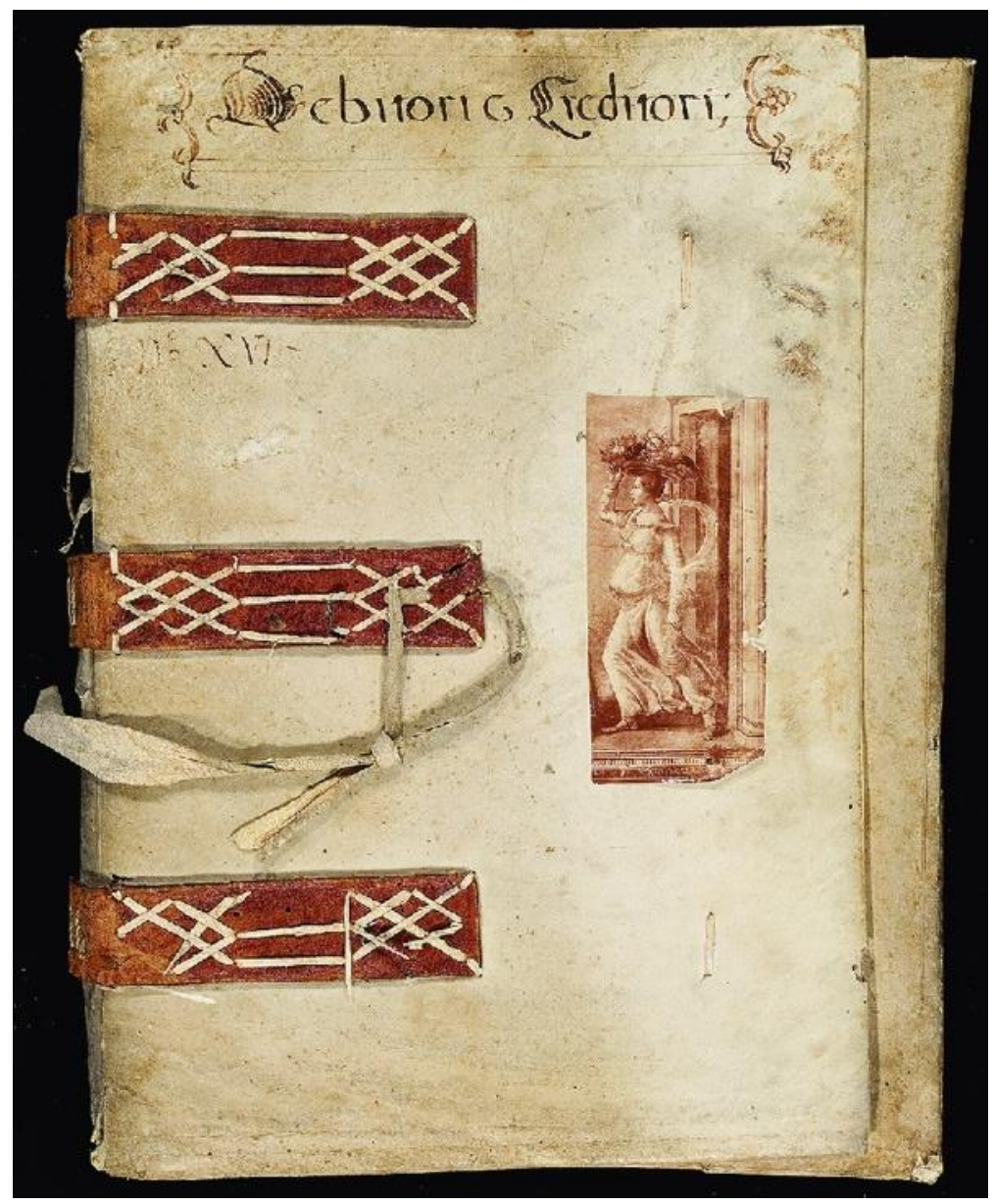

Fig. 2. Ninfa Fiorentina, 1896-1900, capa do manuscrito. Londres, Warburg Institute Archive. Fonte: (Didi-Huberman 2002).

André Jolles fez, então, a conhecida pergunta: "Quem é? De onde vem?" (Jolles, 2018: 70). Aby Warburg teria, por sua vez, respondido: "segundo sua realidade corpórea, pode ter sido uma escrava tártara liberta, mas segundo sua verdadeira essência é um espirito elementar, uma deusa pagã no exílio". Giorgio Agamben escreveu que "a segunda parte da definição (uma deusa pagã no exílio) é a que tem merecido mais atenção dos estudiosos, inscreve a ninfa no contexto mais genuíno das investigações warburguianas, o Nachleben dos deuses pagãos" (Agamben, 2010: 39). Georges DidiHuberman, da mesma forma, coloca-a como o Nachleben der Antike (Didi-Huberman, 2013: 215).

O filósofo italiano dedicou um pequenino e admirável livro - editado pela primeira vez em Roma, no ano de 2007 - à ninfa warburguiana (Agamben, 2010). Ele elegeu como principal objeto, como uma espécie de ninfa mor, a serva de Ghirlandaio. E também mencionou a Prancha 46 do Bilderatlas Mnemosyne, que será tratado na terceira parte deste artigo. Agamben não escreveu precisamente sobre 0 afresco de Santa Maria Novella, mas sobre a já mencionada correspondência trocada entre André Jolles e Aby 
Warburg. Para embasar e analisar tal texto, faz menção a um afamado tratado do século XVI, o qual certamente Warburg e Jolles conheciam. O Livros das Ninfas, Silfos, Pigmos, Salamandras e outros seres (Paracelso, 2004) circunscreve as ninfas como objeto da paixão amorosa por excelência. 0 compêndio que apresenta tradições culturais diversas inscreveu a ninfa como um espírito elemental, estando cada um desses espíritos relacionados a um dos quatro elementos: "a ninfa (ou ondina) à água, os silfos ao ar, os pigmeus (gnomos) à terra e as salamandras ao fogo" (Agamben, 2010: 40).

Estes espíritos elementares, para Paracelso, não seriam nem homens nem animais. Não seriam, tampouco, espíritos propriamente ditos, por causa de sua existência corpórea. Não tinham alma, seriam um híbrido de corpo e espírito. Teriam carnalidade humana, mas movimentar-se-iam como espíritos (Paracelsos, 2004).

Agamben segue seu texto a partir dos escritos do século XVI que articulavam a ninfa ao reino de Vênus e à paixão amorosa. "Condenadas a esse modo a uma incessante busca amorosa do homem, as ninfas levam na terra uma existência paralela. Criadas não a imagem de Deus, mas do homem, constituem uma espécie de sombra ou imagem dele (...)" (Agamben, 2010: 44). A ninfa é, portanto, vista como pertencente ao reino de Vênus e analisada a partir dos preceitos da paixão amorosa.

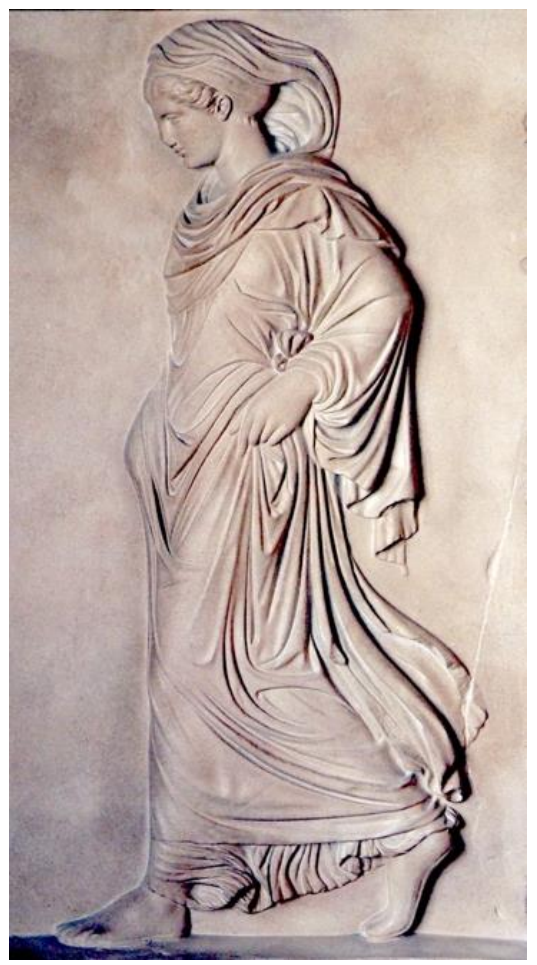

Fig. 3. Detalhe do relevo que atualmente é denominado de Gradiva, século II, baixo-relevo em mármore. Acervo: Museu do Vaticano, Vaticano. Fonte: <http://m.museivaticani.va/content/museivaticani-mobile/en/collezioni/musei/museochiaramonti/gradiva.html>.

Em 1900, Jolles escreveu: "Apaixonamo-nos uma única vez na vida. E quando pensamos estar apaixonados mais uma vez, na realidade, vemos apenas outras faces do mesmo prisma". O apaixonado permanece, o sentimento permanece, o fator de mudança é o objeto. E seria mesmo? Apaixonaríamonos sempre da mesma maneira? A questão direciona a outra imagem, a outra bela e fluida ninfa. Agora não mais de Warburg, mas de Freud: a Gradiva. 
A Gradiva de Freud é a Gradiva de Jensen por excelência. Ela é uma personagem da literatura alemã que tem como referencial imagético um baixo-relevo romano do século II que atualmente faz parte da coleção do Museu do Vaticano. O relevo era originariamente composto pela figura de três mulheres em movimento - que andavam em direção à direita. A primeira figura feminina que compunha essa tríada foi nominada por Jensen de Gradiva, que significa aquela que avança. Sigmund Freud pendurou uma cópia desse relevo contendo uma imagem feminina numa das paredes de seu consultório - justamente acima de seu icônico divã. A Gradiva fora a protagonista de seu livro Delírio e sonhos na "Gradiva" de W. Jensen (1907) (Freud, 2003). Nesse texto, o médico psicanalista responde a uma provocação de Carl Gustave Jung sobre ser ou não possível analisar um sonho que não foi sonhado, mas escrito. E assim o fez; anos depois de escrever e interpretar sonhos sonhados, ele escreve sobre um sonho da literatura. Em A interpretação dos sonhos (1900) (Freud, 2019), Freud analisou e interpretou sonhos a partir de relatos dos seus pacientes. Sete anos mais tarde, ele analisou um sonho escrito por um romancista alemão, em 1903. "A obra era Gradiva, uma pequena narrativa de Wilhelm Jensen, descrita por seu próprio autor como sendo uma "fantasia pompeana"' (Freud, 2003: 12).

O romance de Wilhelm Jensen (1837-1911) narra a história de um arqueólogo - Norbert Hanhold - que, em visita ao Museu Arqueológico Nacional de Nápoles ${ }^{1}$, apaixonou-se pela imagem de uma mulher esculpida num relevo romano do século II. Tratava-se de Gradiva, a imagem de uma jovem e bela mulher com um drapeado vestido. "A escultura representava uma jovem adulta, cujas vestes esvoaçantes revelavam os pés calçados com leves sandálias, surpreendidas ao caminhar" (Ibidem: 12). Na noite posterior à visita em que se encanta com a imagem do relevo romano, 0 arqueólogo sonhou que estava na Pompéia do ano 79 e encontrava a mesma mulher, mas agora em carne e osso. Num angustiante pesadelo, tenta salvar a moça da erupção do Monte Vesúvio (Bredekamp, 2015: 110), mas não consegue avisar a mulher do evento que ocorrerá em breve. Gradiva é então morta e sepultada pelas lavas do vulcão. Freud analisou a relação entre a imagem da Gradiva com um amor de juventude do arqueólogo, um recalcamento do sentimento. "Freud vê nesta repetição do mito de Pigmalião 0 modelo da psicanálise"2 (Ibidem: 111).

Sobre a analogia entre a ninfa e Gradiva, Georges Didi-Huberman escreveu que Freud "(...) começou a seguir, foi cativado pelo passo dançante de Gradiva entre colunas em ruinas e as lavras cinzar de Pompéia" (Didi-Huberman, 2002: 8). A jovem criatura da ficção conseguia reunir memória e desejo na mesma aparição. $O$ objeto da paixão amorosa encontraria sempre uma nova encarnação possível. Como um pesadelo que se deseja sonhar a cada noite. Jolles escreve: "Às suas costas, próxima a porta aberta, correr, ou melhor, voa, ou melhor, paira o objeto dos meus sonhos, que começa, porém, a assumir dimensões de um fascinante pesadelo" (Jolles, 2018: 68). E ele segue indagando: persigo-a ou ela persegue a mim?

A repetição, essa repetição amorosa pode também ser pensada juntamente com a sobrevivência da imagem e de suas formas. Uma imagem pode ser apresentada muitas vezes, mas nunca exatamente da mesma maneira. Waburg teria percebido um modelo fantasmal de história, "(...) no qual os tempos já não se calcavam na transmissão acadêmica dos saberes, mas se exprimiam por obsessões, "sobrevivências", remanências, reaparições das formas" (Didi-Huberman, 2013: 25). Warburg percebeu ninfas da Antiguidade no Renascimento florentino. Mas elas não eram uma simples repetição. Eram outra apresentação possível, uma espécie de recalque de fórmula psíquica. Por isso, o termo utilizado por Warburg, Nachleben, não é uma simples sobrevivência, tal qual traduziu Georges Didi-Huberman. A questão é também linguística, uma vez que a palavra em língua alemã não encontra uma exata 
correspondência para línguas de matriz latina. Como bem coloca Hans Belting, "estamos condenados a viver no labirinto das nossas próprias línguas" (Belting, 2014: 13).

Nachleben é um pós-vida. É algo que morre e volta à vida, se existe um retorno, este não ocorre sem modificações. Tanto a mudança como as permanências são indissociáveis do termo teórico utilizado por Warburg. É interessante analisar o Nachleben juntamente com a teoria freudiana em virtude desses retornos de traumas, recalques, desejos nos sonhos. Podemos associar esse Nachleben imagético de Warburg a um sonho ou um pesadelo que se repete incessantemente. Muitas vezes sonhamos por anos o mesmo sonho, mas jamais ele se repete exatamente da mesma forma. Existem variações, pequenas modificações que marcam essa nova aparição.

Esse modelo de repetição de padrões foi também percebido e analisado por Freud nas relações amorosas. E foi justamente a partir dele que Warburg e Jolles colocaram a ninfa. No manuscrito da Ninfa Florentina, Jolles escreveu que nos apaixonamos apenas uma única vez na vida. Aquilo que acreditamos ser uma nova paixão seria apenas uma outra face do mesmo prisma. Ele segue dizendo: "Modificamos o objeto, mas o enamoramento permanece uno e, em si, único. Assim, dei-me conta, em seguida, de que em muitos aspectos da arte que amei desde sempre, existiu invariavelmente algo da minha ninfa" (Jolles, 2018: 69).

Se um ser humano se apaixona uma ou mais vezes na vida, eu sinceramente não sei responder. Mas, para uma forma de pensamento de Warburg, tais repetições fazem demasiadamente sentido. A repetição de um ornamento, de um gesto, de uma expressão é constantemente recorrente nos textos do historiador da arte. Na ninfa, como bem escreve Jolles, podemos perceber questões da imagem de Warburg.

"Ora, sabemos que essa diferença foi compreendida por Warburg como o evento de uma repetição, ou seja, como a sobrevivência, o retorno inapropriado de um tema greco-romano da Vitória nas paredes de uma igreja florentina do Renascimento" (Didi-Huberman, 2013: 282). Aquela aparição feminina tratava-se de uma Deusa romana da Vitória. Se, no afresco de Ghirlandaio, ela não apareceu alada, a potência do movimento de suas asas pode ser percebida no drapeado esvoaçante de sua túnica. Warburg escreveu sobre a estreita relação entre a serva do afresco e uma escultura da Vitória do Arco de Constantino cujo relevo apresenta a Entrada triunfal de Trajano em Roma. "Uma diferença entre a Deusa da vitória de Trajano e esta Victoria fiorentina casalinga reside no fato de que esta última é representada de perfil. De resto, a oficina de Ghirlandaio tinha disponivel essa posição na coleção de desenhos de modelos antigos" (Warburg, 2018: 116).

\footnotetext{
A Ninfa que paira

A ninfa não consistia em nova personagem para Aby Warburg. Nas páginas de sua tese de doutoramento, ela já está lá, direta e indiretamente. A tese intitulada de $O$ nascimento de Vênus e a Primavera de Sandro Botticelli (Warburg, 2015) foi elaborada sob a orientação de Hubert Janitschek, na Faculdade de Strasbourg (Recht, 2012: 8) - na época pertencente ao território alemão. 0 texto fora submetido à faculdade em dezembro de 1891, aceito em março de 1892 e o diploma oficial de "doutor em filosofia" contém impresso a data de 1893 (Didi-Huberman, 2015: 8). Por fim, a tese foi, pela primeira vez, publicada na cidade natal do historiador - Hamburgo - no ano de 1893. Trata-se do primeiro trabalho universitário do historiador da arte.
} 
0 mote da tese consistia em esclarecer o que, na Antiguidade, "interessava aos artistas do Quattrocento" (Warburg, 2015: 27). Para alcançar tal objetivo, o historiador comparou duas pinturas mitológicas de Sandro Botticelli (1445-1510) - O Nascimento de Vênus (1485) e A Primavera (1482) como outras imagens e textos literários com temática correlata.

Em O Nascimento de Vênus, Warburg teceu paralelos entre a tela de Sandro Botticelli e o conhecido hino Homérico que descrevia o nascimento da deusa do amor por entre as águas do mar Egeu. Todavia, anteriormente à submissão do trabalho, a relação entre a pintura de Botticelli e o texto de Homero eram questionados, já que a tradução de tal texto em Florença data de 1488 - três anos após a finalização dessa têmpera sobre tela. Sendo assim, o historiador defende que seria presumível que o conteúdo da carta já fosse conhecido no círculo humanista de Florença (Warburg, 2015: 29). Tanto os poemas de Homero na Antiguidade, como os escritos por Poliziano no Renascimento foram analisados juntamente à cena pintada por Sandro Botticelli. Ademais, também foram analisadas imagens tanto da Antiguidade, como do Renascimento toscano. "Como se sabe, para resolver o problema do significado que a arte da Antiguidade teve para a sociedade florentina do século XV, Warburg, serviu-se de uma documentação no mínimo variada, ou melhor, visivelmente heterogênea" (Ginzburg, 2007: 45).

Os chamados acessórios em movimento foram o mote da tese de doutoramento. Estes faziam-se visíveis em imagens e legíveis em textos das duas diferentes épocas mencionadas. Warburg aponta que, durante $\circ$ Quattrocento, esses movimentar de acessórios faziam-se também notáveis em textos de conteúdo mais teórico, como no tratado do século XV Da Pintura, de Leon Battista Alberti (2014). "Os esforços ostensivos, que se manifestam uniformemente tanto no poema na pintura, em capturar os movimentos transitórios dos cabelos e trajes corresponde a uma corrente dominante nos círculos artísticos do norte da Itália desde o primeiro terço do século XV" (Warburg, 2015: 33).

Em O Nascimento de Vênus, Warburg fez algumas colocações sobre as diferenças entre a tela de Botticelli e o poema de Homero. Por exemplo, no quadro de Botticelli, a Vênus "(...) cobre os seios com a mão direita, e não com a esquerda (como na poesia)" (Warburg, 2015a: 32). Também aponta para outra mudança efetuada por Botticelli que, ao invés de pintar as três graças recebendo a deusa nua, opta por pintar Flora.

No entanto, o grande objetivo do texto jamais deixa de ser o movimento. E essa inversão no olhar é uma de suas grandes características teóricas na história da arte. Warburg nos ensinou a cultivar uma observação do detalhe, os olhos que não necessariamente fitam aquilo que é mais evidente na imagem: o seu principal tema. Na tese, Warburg deslocou ligeiramente seu olhar para as flutuantes madeixas de cabelos ao vento, para os fluidos e drapeados tecidos. "E está ali, na fórmula de movimento, nessa forma fluente, que ele reconheceu com clareza, o pathos fundamental da imagem" (Didi-Huberman, 2015: 27). Como Didi-Huberman escreve: os personagens de Botticelli estranhamente impassíveis. Todo o movimento se anima nas bordas dos corpos.

No nascimento da deusa do amor é justamente notório o "injetar de vida orgânica nos acessórios inanimados" (Warburg, 2015: 34). Se percebermos atentamente a tela, tudo que se agita não está vivo. Tudo que move incessantemente são as madeixas de cabelo - constituídos de células mortas - e os tecidos das vestes. Nem as águas do mar, muito menos as folhas das árvores apresentam o mesmo movimento drapeado dos tecidos e cabelos. O historiador da arte argentino José Emílio Burucúa (2007: 15) sinaliza que a tese de Warburg identifica a "volta à vida do antigo" como um tema central na produção imagética e literária na Florença do século XV. E faz, então, menção às palavras escritas pelo 
nosso mestre de Hamburgo: das Nachleben der Antike. "Me refiro ao descobrimento de uma fórmula significativa, a ninfa ou jovem mulher em movimento gracioso de membros, cabelos e vestimentas, que aparecia de maneira recorrente nas representações literárias, pictóricas e cerimoniais (...) (Ibidem: 15). O Nachleben der Antike, essa "volta à vida do antigo", foi identificado por Aby Warburg nessa espécie de fórmula do movimento.

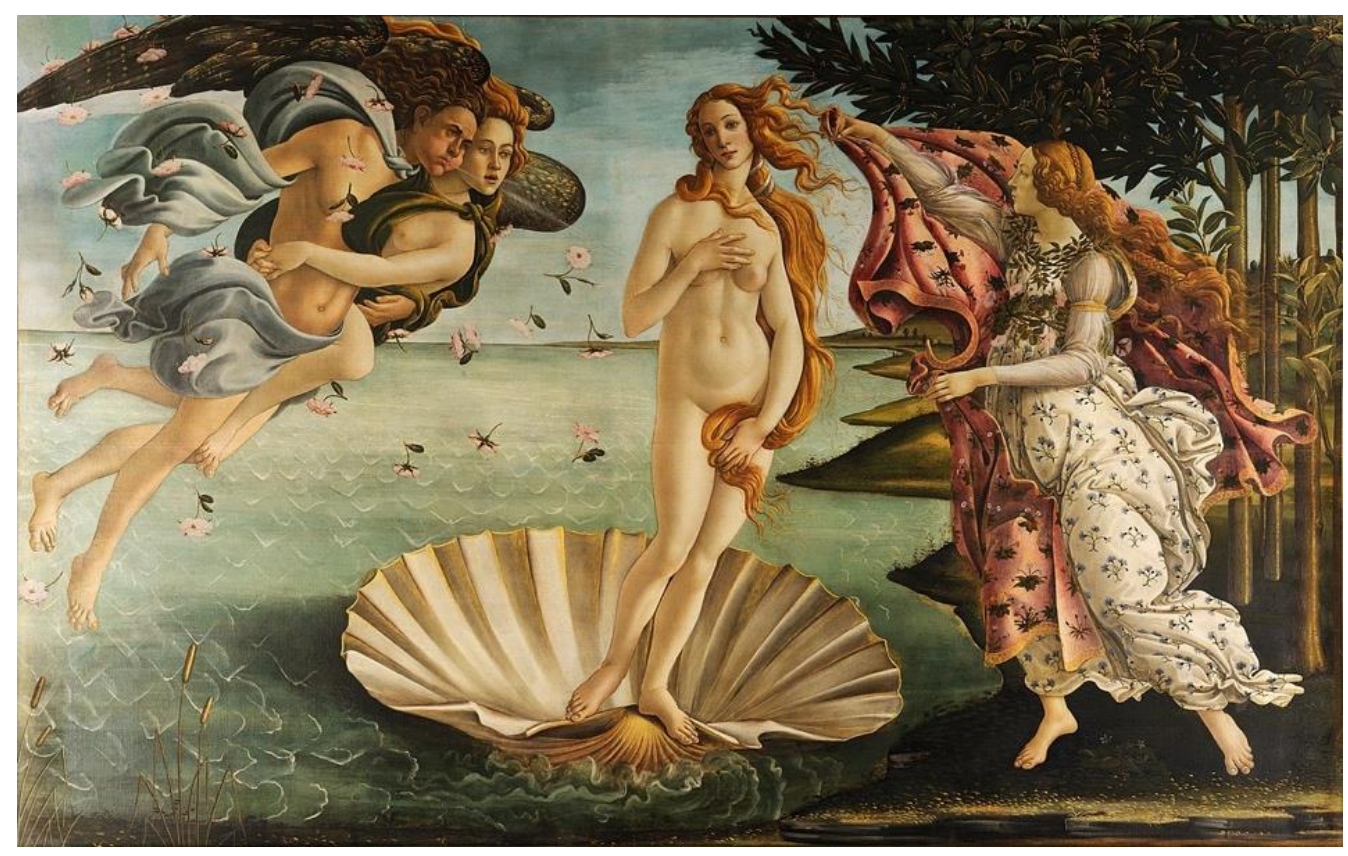

Fig. 4. Sandro Botticelli, O Nascimento de Vênus, c. 1485, têmpera sobre tela, Florença, Galleria degli Uffizi. Fonte: (Warburg, 2015a).

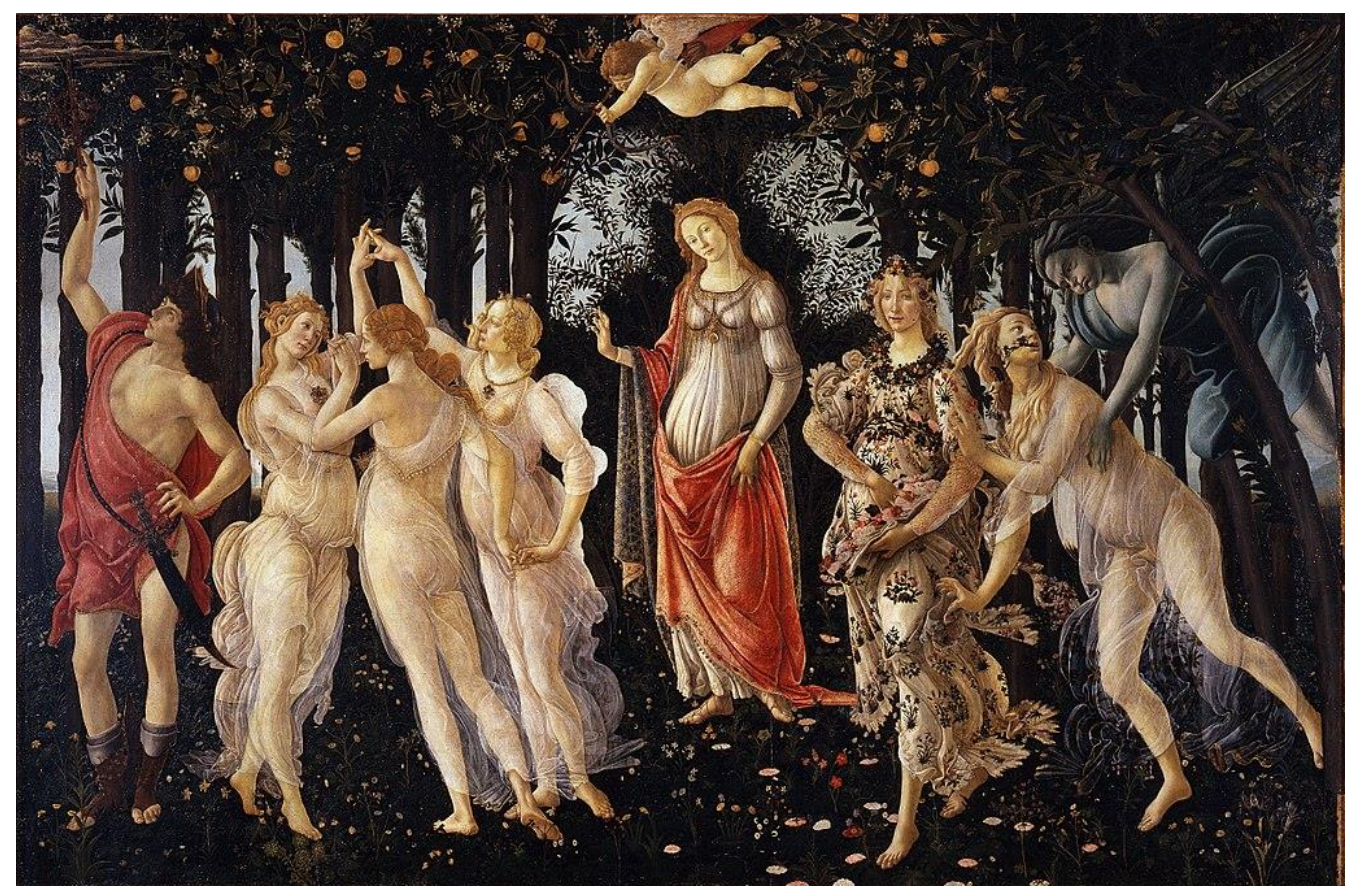

Fig. 5.Sandro Botticelli, A Primavera, c. 1482, têmpera sobre painel. Florença: Galleria degli Uffizi. Fonte: (Warburg, 2015a). 
Em dezenas de obras analisadas por Warburg, sejam pinturas, desenhos, relevos, poemas, textos teóricos, romances "(...) em todos esses casos, fez-se presente a inclinação (formada com base no que então se sabia da Antiguidade) em recorrer às obras de arte da Antiguidade, quando se tratava de se dar corpo à vida em movimento aparente" (Warburg, 2015: 49).

Nos textos escritos em manuscritos de forma fragmentária entre 1888 e 1905 - publicados em Fragments sur l'expression (Warburg, 2015b) - fazem-se notáveis um significativo número de notas sobre o drapeado e o movimento, em especial nas vestimentas. No ano de 1889, após uma estadia em Florença e já em Frankfurt, ele tomou nota sobre os motivos de vestimentas em movimento na arte florentina do Quattrocento. Indica que, se na primeira metade daquele século, o movimento das vestimentas não era motivado pelo movimento dos corpos, na segunda metade do século $\mathrm{XV}, 0$ movimento da vestimenta é afetado pelo movimento simultâneo nos corpos. Todavia, em ambos os casos, percebe o movimento das vestimentas contrário às condições naturais como "a influência da Antiguidade em pintura e esculturas" (Ibidem: 68). No mesmo ano, ainda escreve que, na primeira metade do século XV, nota "figuras singularmente imóveis e vestimentas animadas em senso contrário" e na segunda metade "o movimento das vestimentas é motivado pelo movimento da figura e pelo vento" (Ibidem: 74).

No caso dos dois quadros de Botticelli analisados na tese, o vento que agita a cena sai especificamente de boca de Zéfiro - o deus do vento. Já no afresco O Nascimento de São João Batista de Ghirlandaio, o vento não sai da boca de um deus, o drapeado formado na túnica da ninfa é decorrente do próprio movimento de seu corpo, a ninfa pagã no exílio corre, paira e até voa. Sendo assim, como as três imagens citadas foram produzidas na segunda metade do Quattrocento, o formar de seus respetivos movimentos estão de acordo com as notas tomadas pelo historiador da arte no ano de 1889.

O conceito de Pathosformel foi usado pela primeira vez por Aby Warburg em seu artigo "Dürer e a Antiguidade italiana" (Warburg, 2015a). Nesse artigo, o historiador investigou um desenho da Morte de Orfeu (1494), de Albrecht Dürer, e uma gravura de cobre do círculo de Mantegna (Warburg, 2015: 87). Nessas imagens, Warburg identificou uma mímica pateticamente acentuada que artistas italianos da segunda metade do século XV utilizam como modelos as formas da Antiguidade (Ibidem: 89). Uma das questões mais interessantes da Pathosformel warburguiana é que, muitas vezes, gestos similares na história da arte podem - ou não - assumir significados diferentes e também opostos. Mesmo que 0 conceito não tenha sido usado efetivamente na tese doutoral, podemos reconhecê-lo. No segundo parágrafo da tese, Warburg escreve que seria possível comparar gradualmente como "artistas e seus conselheiros viam na "Antiguidade" um modelo que requer o movimento aparente acentuado, e como se apoiavam nos modelos antigos quando se tratava de representar partes acessórias - como o traje e os cabelos - cujo movimento é aparente" (Warburg, 2015a: 27). Didi-Huberman identifica o "movimento amplificado - intensificado - como ferramenta formal de uma memória da Antiguidade? Warburg antecipou ali aquilo que nomearia de "fórmula pathos" (Pathosformel)" (Didi-Huberman, 2015: 25).

É perceptível uma divergência na compreensão - ou talvez na disseminação - do conceito de Pathosformel em alguns exegetas de Warburg. A que se faz mais notória está entre os escritos do historiador italiano Carlo Ginzburg e de Georges Didi-Huberman. Sendo que, para o primeiro, essas formas são transmitidas culturalmente, e para o segundo, não unicamente. Ambos fazem referência às teorias darwinianas. $O$ então jovem pesquisador Aby Warburg, ao ter entre suas mãos um exemplar do livro Expressão das Emoções no Homem e nos Animais (Darwin, 2009) escreveu em seu caderno de notas: enfim um livro que me é útil. No livro, Charles Darwin analisou as expressões de emoção 
sobretudo em crianças e em animais e concluiu que as emoções - ou melhor, a expressão física delas - constitui num ato primitivo.

Para Carlo Ginzburg, a Pathosformel consistia numa "fórmula estilística arcaizante, imposta, por assim dizer, pelos temas e situações particularmente emotivo - estabelecia na análise uma estreita ligação entre forma e conteúdo" (Ginzburg, 2007: 65). O historiador italiano pensa a Pathosformel relacionada à compreensão que Warburg tinha das teorias de Friedrich Nietzsche. Relaciona, assim, essas expressões-limite estilizadas ao pathos dionisíaco. Com a noção de Pathosformel, as representações dos mitos da Antiguidade foram também entendidas como testemunhos de emoções transformados em imagens, nas quais poderia-se identificar traços das comoções essencialmente humanas" (...) segundo a interpretação da mímica e dos gestos como vestígio de violentas paixões experimentadas no passado (...)" (Ibidem: 45).

Sobre a análise de Warburg acerca do livro de Darwin, Georges Didi-Huberman escreveu que "Chorar, estão: exprime, por músculo e secreção, por gestos e lágrimas, uma emoção ou um pathos" (DidiHuberman, 2016: 14). Ele seria uma espécie de reação espontânea a um sofrimento ou uma alegria extrema. Tal emoção viria do interior e alcançaria a expressão no exterior do corpo. 0 gesto seria, então, primitivo. "Isso significa que as emoções passam por ser gestos que efetuamos sem nos darmos conta de que vêm de muito longe no tempo. Esses gestos são como fósseis em movimento. Tem uma história muito longa e muito inconsciente. Eles sobrevivem em nós (...)" Didi-Huberman, 2015: 32).

Tal qual Carlo Ginzburg e Georges Didi-Huberman, Horst Bredekamp compreende a "fórmula pathos" como uma fórmula de emoção. A Pathosformel é compreendida por ele como a aliança de duas componentes opostas: o pathos e o do ethos. 0 pathos seria a reação corpórea intensificada de uma alma abalada, e ethos o elemento que se incube do controle das emoções como fórmula (Bredekamp, 2015: 225). Bredekamp identifica nas ninfas, justamente no movimento dos cabelos e das vestes, uma das manifestações mais refinadas dessa "fórmula pathos". "A testemunha de Warburg era Alberti que no seu tratado De pictura [Da Pintura] atribuiu não só ao rosto e aos gestos, mas sobretudo aos arranjos dos cabelos e das vestes, a capacidade de poder expressar os movimentos da alma" (Ibidem: 237).

A ninfa seria a personagem que apresentaria em suas madeixas e vestidos esse movimento da alma. Fixar o movimento da vida em uma imagem fora uma das grandes questões dos antigos que pareceu voltar à tona no Renascimento toscano. A vida humana é o elemento fundamentalmente fugaz. A imagem é, frente à vida, o elemento de sobrevivência. A certeza, ou a esperança, que temos é que a imagem sobreviva a nós. E como apresentar o movimento de algo tão volátil como a vida numa materialidade mais duradoura, seja ela pedra, madeira ou tela. Essa é uma das mais profundas e antigas questões que o homem travou com a imagem. Essa é uma das mais profundas e angustiantes questões que parecemos querer resolver com a ninfa.

Pensar a ninfa como uma personagem teórica warburguiniana a inscreve exatamente como heroína de um tempo distante que sempre retorna. Ela é o Nachleben de uma Antiguidade pagã que chegou até 0 Renascimento por mármores de sarcófagos, arcos de triunfo, estátuas. Ela também é a Pathosfomel que, em seus drapeados, expressa o pathos de uma emoção interior. Georges Didi-Huberman escreve que, em $O$ Nascimento de Vênus e A Primavera, Sandro Botticelli criou um gênero de quadros antes inexistente, no qual podemos ver divindades antigas praticamente nuas em tamanho natural. "Aby Warburg, quatro séculos depois, criou um novo gênero de história da arte" (Didi-Huberman, 2015: 20). 


\section{A Ninfa que voa}

Ao término de uma estadia de pesquisa junto ao Instituto Warburg, Giorgio Agamben (2007) escreveu o conhecido Aby Warburg e a ciência sem nome, publicado pela primeira vez em no periódico Prospettive settanta de 1975. No texto ensaístico, o filósofo italiano analisa as contribuições intelectuais de Aby Warburg e faz menção ao livro A forma inteligível de 1970 (Klein, 1998), de Robert Klein. Neste, Klein defende que o historiador da arte alemão foi o criador de uma disciplina, que, ao contrário de tantas outras, existe, mas não tem nome. Agamben, do mesmo modo, argumenta que a disciplina fundada por Warburg seria inominada. Ao se questionar se ela poderia receber um nome, ele propõe um. "A ciência que havia recorrido então ao seu gesto o conhecimento libertador do humano mereceria realmente ser chamada do nome grego de Mnemosyne" (Agamben, 2007: 149). Para Agamben, o nome da deusa grega da memória seria o nome da ciência inventada por Aby Warburg.

A palavra grega Mnemosyne está intimamente relacionada ao nome de Aby Warburg. Em primeiro lugar, porque acima da porta de entrada de sua Kulturwissenschaftliche Bibliothek Warburg, o historiador da arte colocou uma placa como nome da deusa. A divindade que preservou o mundo antigo do esquecimento (Yates, 2015: 17) também foi incumbida de proteger o legado de livros e imagens formado por Aby Warburg. Em seguida, porque foi o nome atribuído ao grande Atlas de imagens montado e remontado pelo historiador.

O Bilderatlas Mnemosyne foi o último e inacabado trabalho de Warburg. Ao qual dedicou-se sem interrupção de 1924 até sua morte, em 1929 (Rech, 2012: 25). É demasiado difícil encontrar uma única e boa definição para resumir do que se tratou aquele grande projeto. Para Didi-Huberman, "(...) não era apenas um "resumo em imagens', mas um pensamento por imagens" (Didi-Huberman, 2013: 383). Segundo o historiador da arte Fritz Saxl, a grande problemática da labiríntica Kulturwissenschaftliche Bibliothek era a sobrevivência da Antiguidade (Saxl, 2010: 107). E a problemática do Atlas que nela foi montado não era muito diferente. Warburg escreveu que "com seu encontro de imagens "Mnemosyne" quer ser antes de tudo um inventário dos modelos antiquizantes preexistentes que influenciaram na representação da vida em movimento e determinaram o estilo artístico da época do Renascimento" (Warburg, 2010: 3). É visível que as pranchas que compõem o Atlas não se restringem à Antiguidade e ao Renascimento. As imagens ali colocadas por presilhas contemplam muitos outros séculos e épocas.

$\mathrm{Na}$ incessante busca por elementos da Antiguidade que sobreviveram - ou melhor, que encontraram uma pós, e por vezes, diferente vida - em outros tempos históricos, o movimento saltou aos olhos de Warburg desde sua tese doutoral até seu último trabalho, o Bilderatlas. Por tal motivo, a ninfa pode ser percebia como uma espécie de personagem teórica para o historiador. Uma vez que ela figura justamente nessa vida em movimento. Ela correu, pairou e até voou por entre os escritos do intelectual hamburguês. Contudo, foi estudada de forma mais atenta, em especial, nesses três trabalhos analisados neste breve artigo.

O Bilderatlas Mnemosyne compõe uma breve introdução de notas escritas por Aby Warburg e organizadas pela sua assistente e também historiadora da arte Gertrud Bing. Para além da introdução o Atlas era composto por mais de mil reproduções fotográficas distribuídas em Pranchas. Em muitas das quais vemos a "divindade menor sem poder instituído" que se apresentava ora como serva, ora como Vitória, ora como a dançante e bíblica Salomé. A personagem está em muitas imagens que compõem muitas das pranchas desse Atlas. "A "ninfa" que Warburg descobre em tantos lugares como imagem do movimento e imagem em movimento" (Lahuerta, 2015: 22). 
Marcadamente, as ninfas são dadas a ver como a problemática das Pranchas 39, 46 e 77. No entanto, a divindade menor como ser alado voa por entre muitas outras pranchas negras naquele intento de contar uma história da arte sem palavras. A Prancha de número 77 é, muito provavelmente, a mais icônica ao abordar a ninfa. Pois, como figura central não temos uma ninfa da Antiguidade ou do Renascimento, mas uma do século XX. Essa ninfa não foi esculpida em mármore, nem pintada à tempera ou à óleo. Ela foi feita imagem através do processo de reprodutibilidade técnica (Benjamin, 2010) da imagem inventado no século XIX. Trata-se de uma fotografia, de uma fotografia de uma fotografia. Como mais uma contribuição de Warburg para a história da arte, temos a ampliação de seu objeto. Outrora inscrito apenas no considerado objeto de arte, agora ganhava o mundo como imagem e suas mais amplas facetas. "A história das artes cingia-se, portanto às meras formas artísticas. 0 protesto contra esta concepção veio do círculo de Aby Warburg, em Hamburgo, onde da ciência da arte [Kunstwissenschaft] deveria surgir uma ciência da cultura [Kulturwissenschaff] de um outro tipo" (Belting, 2014: 27).

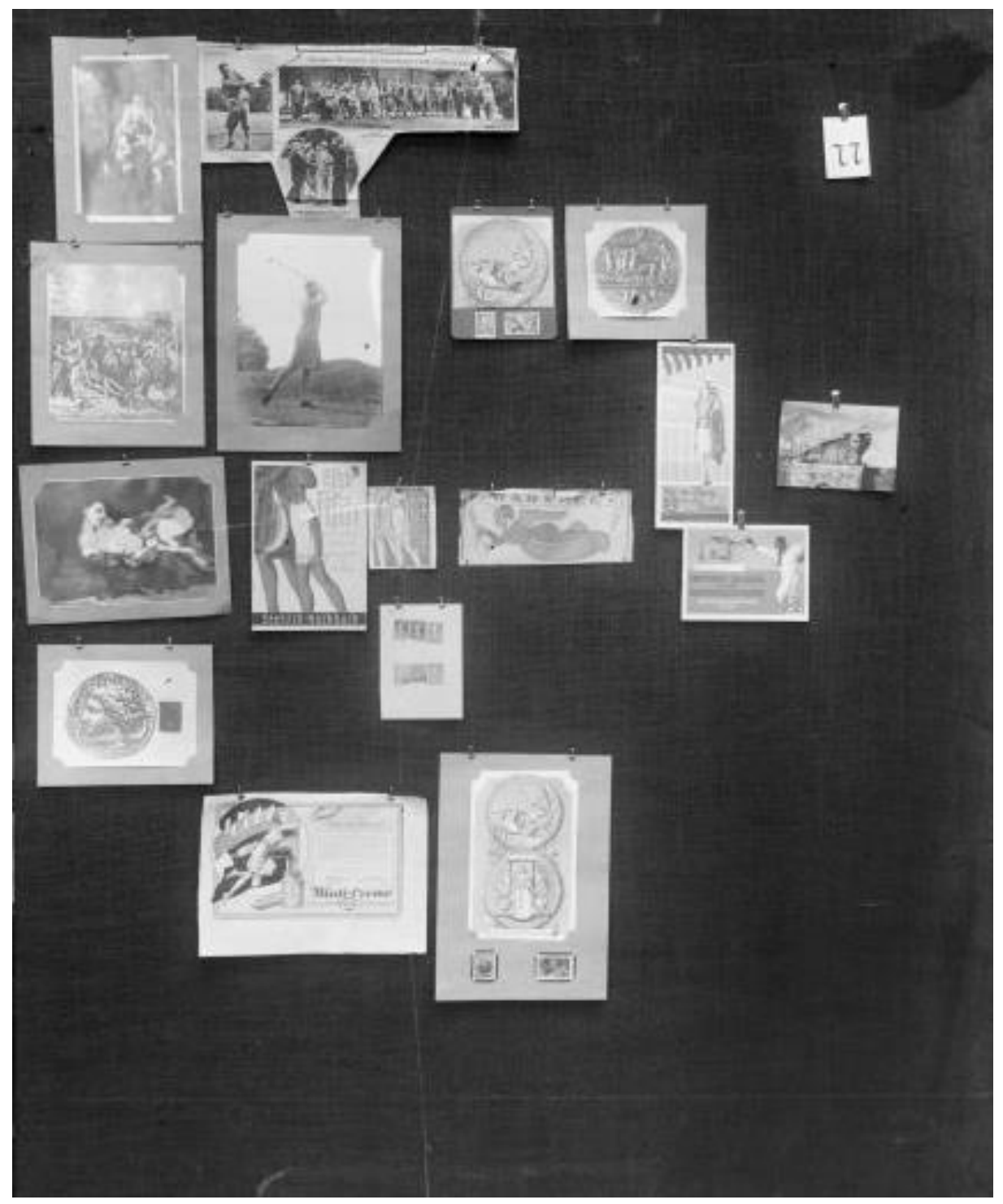

Fig. 6. Aby Warburg, Prancha 77 do Bilderatlas Mnemosyne, reproduções fotográficas sobre painel de madeira e tecido, 1929. Fonte: (Warburg, 2010). 
A deusa pagã no exílio estava ali, naquele projeto encarnada como uma golfista. Naquela prancha, Warburg colocou como imagem central uma fotografia da, na época, célebre Erika Sell-Schopp. A fotografia esportiva apresenta o movimento da vida expresso numa ação do corpo. A fotografia do século XX apresenta fixado em imagem o movimento do corpo de uma golfista que, por descompasso parece imitar uma estátua antiga. Uma heroína olímpica que parece imitar o gesto de uma heroína do olimpo. "Como não ver, nesta golfista preste a bater sua bola, a antiga ninfa assassinando Orfeu com um golpe de vara. E então Warburg havia bem estudado as sobrevivências em Mantegna e em Dürer" (Didi-Huberman, 2002: 134).

Nesta prancha, vemos tantas outras imagens de ninfa apresentadas a partir de modernas técnicas de reprodutibilidade da imagem. Temos uma ninfa apresentada na capa de um livro de cozinha e uma outra, belamente alada, num anúncio publicitário de Matt-Creme $e^{3}$. "Todavia, suas análises formais não se detiveram aos pressupostos formais e iconográficos da cultura clássica. 0 que interessou principalmente a Warburg foram os modos em que estas figuras conectam um tempo histórico com outro" (Szir, 2019: 24).

Mas as imagens da Prancha 77 que mais fazem meus olhos abrir e fechar são, muito provavelmente, as mais comuns, as mais corriqueiras: são imagens de selos postais.

Na parte inferior e ao lado da imagem da golfista, temos duas tríades de selos postais da Casa Real da Inglaterra. Uma do século XVII e outra do século XIX. Nos selos do dezenove, vemos a Rainha Vitória numa carruagem de conchas, como a ninfa de $O$ triunfo de Galateia (1512) que Rafael (1483-1520) pintou no afresco da Villa Farnesina de Roma. E, no do século XVII, o rei da Inglaterra Carlos II foi apresentado como o deus romano dos mares: Netuno. Nas fotografias desses corriqueiros objetos, temos imagens cujos detalhes aludem à sobrevivência de um mundo Antigo, ou de uma (re) apresentação, uma visualidade, possível dele. Uma Antiguidade que temporalmente se foi, mas que por imagens continua a fazer-se presente em outros tempos. Nessas imagens, temos uma outra vida possível para divindades e formas de um outro tempo. Nesse caso específico, quiçá o mais incrivel seja o próprio objeto: o selo postal. Um pedacinho de papel que se cola em outro papel e possibilita que este atravesse 0 espaço, 0 selo permite a passagem para outro lugar. Justamente nesse pedaço de permissão de fluxo de entrada e saída para distintos lugares temos imagens que parecem ter a permissão de fluxo de entrada e saída para distintos tempos. Estes objetos constituem a imbricação de espaço e tempo.

Warburg passa a sua vida a pesquisar - a caçar - as sobrevivências de uma Antiguidade, de um paganismo. Seus escritos as identificaram numa porção de lugares e tempos. É no Bilderatlas Mnemosyne que encontramos visualmente seus mais amplos e múltiplos espectros de possibilidades temporal. E a nossa personagem - a ninfa - parece estar por toda parte e visitar múltiplos tempos, seja ele antigo ou moderno. Na reveria [rêverie] individual "(...) warburguiniana sobre uma fotografia de uma golfista pensada como a sobrevivência das ninfas antigas, se encontra lançada uma hipótese sobre a necessidade coletiva, cultural, de uma sobrevivência moderna dos deuses pagãos em geral" (DidiHuberman, 2002: 136).

Nesse último e inacabado projeto, Warburg retoma boa parte das pesquisas empreendidas por ele ao longo de sua vida. Na Prancha número 39 [Fig. 7], ele retoma as imagens de sua tese doutoral. Reproduções fotográficas de $O$ Nascimento de Vênus e $A$ Primavera dividem a prancha negra com 
desenhos tomados de um antigo sarcófago romano e outras tantas possibilidades de apresentação da ninfa durante o Renascimento. Ela é Pala Atena, Chloé, Dafne, alegoria da Fortuna e da Abundância.

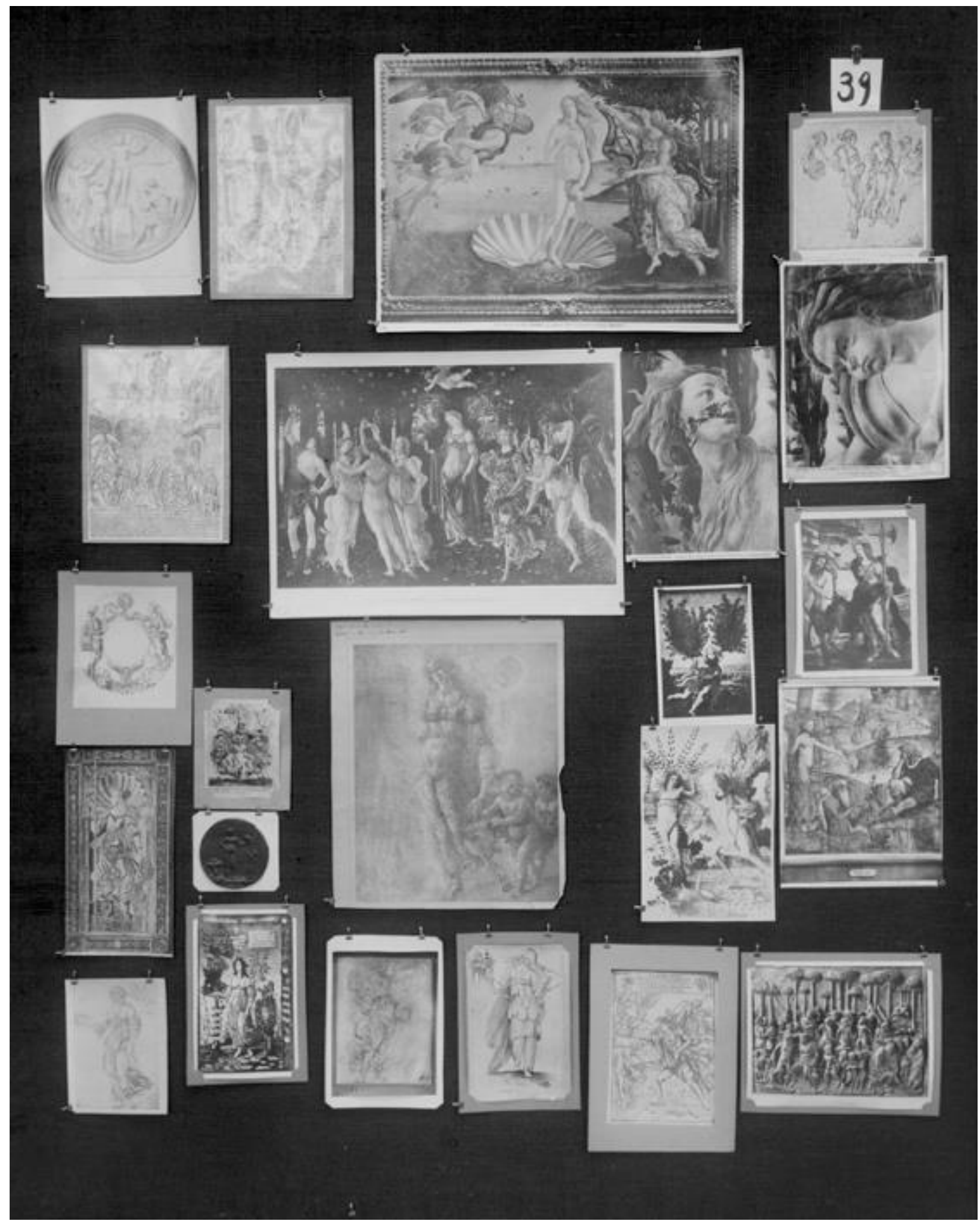

Fig. 7. Aby Warburg, Prancha 39 do Bilderatlas Mnemosyne, reproduções fotográficas sobre painel de madeira e tecido, 1929. Fonte: (Warburg, 2010). 


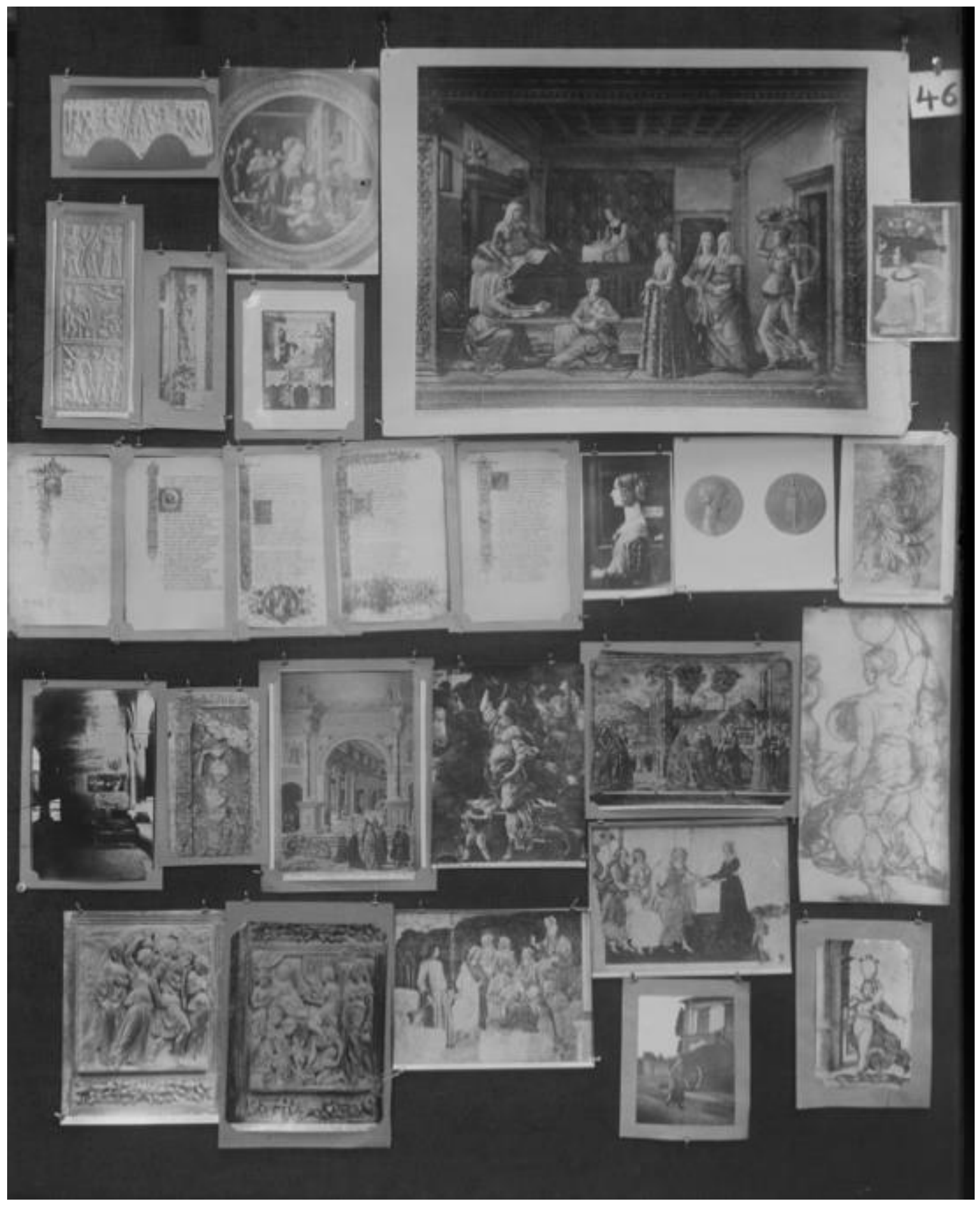

Fig. 8. Aby Warburg, Prancha 46 do Bilderatlas Mnemosyne, reproduções fotográficas sobre painel de madeira e tecido, 1929. Fonte: (Warburg, 2010). 
$\mathrm{Na}$ Prancha número 46 [Fig. 8], o historiador da arte retoma sua grande ninfa: a de Ghirlandaio. 0 gesto da serva que carrega um cesto de frutas frescas sobre a cabeça é reconhecido em outras imagens: são desenhos do círculo de Rafael, num detalhe da tela Virgem e menino com a História da vida de Sant'Ana (1452) de Filippo Lippi (1406-1469). Na Prancha também podemos ver a ninfa no retrato de Giovana Tornabuoni em tela, afresco e mesmo na cunhagem de uma moeda. Na Prancha número 47, a ninfa também aparece com uma caçadora de cabeças. Ela é Salomé com a cabeça de São João Batista que Donatello (1386-1466) forjou numa pia batismal, e a Judite que Botticelli pintou com a cabeça de Holofernes. Na Prancha número 42 ela é Maria Madalena em delírio aos pés de Jesus Cristo crucificado - o relevo em bronze Crucificação [1490] de Bertoldo di Giovanni (?-1491), uma Pathosformel de uma mênade num rito dionisíaco. "A Salomé dançarina da Bíblia aparece como mênade grega, ou no momento em que a servente que traz cesto de frutos de Ghirlandaio vem correndo bem ao estilo da Vitória de um arco do triunfo romano, em uma imitação plenamente consciente" (Warburg, 2015: 367). As ninfas na Antiguidade Clássica eram divindades femininas menores. Elas receberam diferentes formas e nomes e usualmente estavam vinculadas à natureza. Eram as habitantes de lagos e rios, passeavam por entre bosques e florestas, movimentavam-se por entre grutas e montanhas. No entanto, “(...) as ninfas identificadas por Warburg transgrediam esses amplos atributos. Vênus, Vitória, Hora, Aura, Ménade, Judith ou Salomé atravessam os quadros do Renascimento em múltiplas identificações iconográficas" (Szir, 2019: 24).

Aby Warburg escolhera uma boa deusa para proteger sua Kulturwissenschaftliche Bibliothek e para nomear seu Bilderatlas. No mundo antigo - aquele que apenas existe em textos e imagens e no olhar perspicaz de alguns pesquisadores -, Mnemosyne é uma fonte de água, uma fonte da memória. Os antigos diziam que os seres humanos mortos ao beber a água desse mítico poço relembram suas outras vidas. Aquelas águas tinham o poder de fazer sobreviver a memória de outras vidas. Nesse mesmo mundo de outrora, a deusa Mnemosyne era filha de Urano e Gaia e, a partir de relações com Zeus, foi mãe das nove musas da inspiração poética (Brandão, 2010: 140). "Mnemosyne, personificação clássica da memória, mãe das nove Musas e, suspeitamos, vagamente aparentada com a Ninfa" (DidiHuberman, 2013: 383).

\section{A ninfa que corre, paira, voa e persegue}

A bela e fugidia ninfa foi uma personagem warburguiana. $O$ historiador da arte hamburguês a percebeu em muitos lugares e tempos. Para além de uma personagem ora identificada como serva, ora como golfista ou Vitória, ela pode ser pensada como uma personagem teórica. Isto porque, através da imagem da ninfa podemos entender e problematizar importantes conceitos teóricos abordados por Aby Warburg. o Nachleben, a Pathosformel, o Mnemosyne parecem ganhar vida na imagem de uma divindade menor na qual o estudioso percebeu a imagem da vida em movimento.

Como um autêntico Nachleben der Antike as ninfas não cessaram suas figurações na Antiguidade ou no Renascimento. E, como autêntica personagem teórica, elas não deixaram de ser problematizadas após a morte de Aby Warburg. As ninfas continuam por aí, aparentemente por toda parte. Seja nas salas dos modernos museus ou em novas apresentações possiveis em imagens de arte. Elas estão até mesmo em anúncios publicitários e posts do Instagram. Elas ainda são analisadas e problematizadas por muitos pesquisadores que dedicam a elas muitos textos. Muitos exegetas, os chamados herdeiros intelectuais, de Warburg continuam a buscá-las, persegui-las. Ou será que são elas que não cessam jamais de persegui-los? 


\section{Referências}

AGAMBEN, G. Aby Warburg y la ciencia sin nombre. In: La potencia del pensamiento. Buenos Aires: Adriana Hidalgo, 2007. Ninfas. Valencia: Pre-Textos, 2010.

ALBERTI, L.B. Da Pintura. Campinas: Editora Unicamp, 2014.

ARASSE, D. Histórias de pinturas. Lisboa: KKYM, 2016.

BELTING, H. Antropologia da Imagem: por uma ciência da imagem. Lisboa: KKYM, 2014.

BENJAMIN, W. A obra de arte na era de sua reprodutibilidade técnica. In: Obras Escolhidas, vol. 1. Ensaios sobre literatura e história da cultura. São Paulo: Brasiliense, 2010.

BRANDÃO, J. Dicionário Mítico-Etimológico. Petrópolis/RJ. Editora Vozes: 2010.

BREDEKAMP, H. Teoria do ato icônico. Lisboa: KKYM, 2015.

BURUCÚA, J. E. Historia, arte, cultura. De Aby Warburg a Carlo Ginzburg. Buenos Aires: Fondo de Cultura Económica, 2007.

CHECA, F. La Biblioteca de Aby Warburg: "orientación" para la mente y "arena" para la Historia del Arte. In: SETTIS, S. Warburg Continuatus: Descripción de una biblioteca. Madrid: Ediciones de La Central, 2010.

DARWIN, C. Expressão das Emoções no Homem e nos Animais. São Paulo: Companhia das Letras, 2009.

DIDI-HUBERMAN, G. A imagem sobrevivente. História da arte e tempo dos fantasmas segundo Aby Warburg. Rio de Janeiro: Editora Contraponto, 2013.

Ninfa Dolorosa: Essai sur la mémoire d'un geste. Paris: Gallimard, 2019.

Ninfa Moderna: Essai sur le drapé tombé. Paris : Gallimard, 2002.

Ninfa Profunda: Essai sur le drapétourmente. Paris: Gallimard, 2017.

Peuples en larme, Peules en armes. L'CEil de l'histoire, 6. Paris : Minuit, 2016. KKYM, 2015

Que Emoção! Que Emoção? Lisboa:

FREUD, S. A interpretação dos sonhos. São Paulo: Companhia das Letras, 2009.
. Delírios e sonhos na Gradiva de Jensen. Rio de Janeiro: Imago Editora, 2003

GINZBURG, C. Medo, reverência, terror: quatro ensaios de iconografia política. São Paulo: Companhia da Letras, 2014.

Mitos, Emblemas, Sinais: Morfologia e História. São Paulo: Companhia das Letras, 2007.

HUCHET, S. A história da arte, disciplina luminosa. Revista UFMG, Belo Horizonte, v.21, n. 1 e 2, p. 222-245, jan/dez. 2014. Disponível em:<https://periodicos.ufmg.br/index.php/revist adaufmg/article/view/2649>.

KLEIN, R. A forma inteligível: Escritos sobre Renascimento e Arte Moderna. São Paulo: Edusp, 1998.

LAHUERTA, J. J. Aby Warburg Marginalia Carl Einstein. Madrid: Ediciones Asimétricas, 2015.

OVÍDIO. Metamorfose. Lisboa: Livros Cotovia, 2007.

PARACELSO. Libro De Las Ninfas, Los Silfos, Los Pigmeos, Las Salamandras y los Demás Espíritus. Madrid: Obelisco Ediciones, 2004.

RECHT, R. L'Atlas Mnemosyne d'Aby Warburg. In: WARBURG, A. L'Atlas Mnémosyne. Paris: l'Écarquillé, 2012.

SAXL, F. La Kulturwissenschaftliche Bibliothek Warburg en Hamburgo. In: SETTIS, S. Warburg continuatus: Descripción de una biblioteca. Barcelona: Ediciones La Central, 2010.

SZIR, S. A Ninfa. In: BURUCÚA, J.E. Ninfas, Serpientes, Constelaciones. La Teoría artística de Aby Warburg. Buenos Aires: Museo de Bellas Artes, 2019.

WARBURG, A. A presença do antigo: Escritos inéditos. Vol. 1. Campinas: Editora Unicamp, 2018.

Atlas Mnemosyne. Madrid: AKAL, 2010.

História de fantasmas para gente grande. São Paulo: Companhia das Letras, 2015a.

Fragments sur l'expression : Textes établis et présentés par Susanne Müller. Paris: L'écarquillé, 2015b.

YATES, F. A. A arte da memória. Campinas: Editora da Unicamp, 2015. 


\section{Notas}

" Professora de História da Arte da Universidade Federal de Santa Catarina. Pós-doutorado pelo Centre d'Histoire et de Théorie des Arts da École des Hautes Études en Sciences Sociales de Paris sob a supervisão de Georges Didi-Huberman, com bolsa concedida pelo CNPq. E-mail: <camposdanielaqueiroz@gmail.com>. ORCID: <https://orcid.org/0000-0002-9681-0977>.

${ }^{1}$ No romance citado, o arqueólogo vê a imagem no Museu Arqueológico Nacional de Nápoles. Todavia, sublinho que o relevo mencionado faz parte do acervo do Museu do Vaticano.

2 Pigmalião é um dos muitos contos Ocidentais em que um homem se apaixonou pela imagem de uma mulher. Segundo Ovídio (2007), Pigmaleão foi o rei da llha de Chipre que se apaixonou pela escultura de marfim de mulher que ele próprio esculpira, denominada de Galatéia.

${ }^{3}$ Entre as imagens da Prancha 77 podemos visualizar a reprodução fotográfica de um anúncio publicitário do início do século XX de um creme hidratante - o Matt-Creme.

Artigo recebido em maio de 2020. Aprovado em julho de 2020. 